\title{
Studi Ketersediaan Sumber Air Untuk Pemenuhan Kebutuhan Rumah Tangga di Desa Ranggagata Kecamatan Praya Barat Daya Kabupaten Lombok Tengah.
}

\author{
Harry Irawan Johari, "Roy Maulana Ansori, Alfian Pujian Hadi \\ Progra Studi Pendidikan Geografi Universitas Muammadiyah Mataram \\ *maulanaansori96@gmail.com
}

INFO ARTIKEL
Riwayat Artikel:
Diterima: $20-05-2020$
Disetujui: 16-08-2020

Kata Kunci:

Studi Ketersediaan

Air Bersih

Kebutuhan

Rumah Tangga

\begin{abstract}
ABSTRAK
Abstrak: Desa Ranggagata Kecamatan Peraya Barat Daya Kabupaten Lombok Tengah " yang mana daerah ini mengalami masalah pada sumber air bersih. Tujuan penelitian ini untuk mengetahui ketersediaan sumber air bersih yang digunakan penduduk untuk memenuhi kebutuhan rumah tangga dan upaya yang dilakukan oleh masyarakat untuk menanggulangi kekurang air bersih di Desa Ranggagata Kecamatan Praya Barat Daya Kabupaten Lombok Tengah. Metode penelitian menggunakan penelitian kualitatif dengan teknik pengumpulan data dalam penelitian menggunakan observasi, wawancara dan dukumentasi. Analisis data dengan model interaktif analisis dengan reduksi. Hasil penelitian dapat disimpulkan bahwa ketersediaan air bersih di desa Ranggagata sudah mengupayakan semaksimal mungkin supaya di tahun 2020 sudah terpenuhi dan upaya dalam menanggulangi kekurangan air bersih sudah ada bantuan dari kepala desa maupun dari PDAM.
\end{abstract}

\begin{abstract}
Ranggagata Village, Praya Barat Daya District, Central Lombok Regency " where this area has problems with clean water sources. The purpose of this study was to determine the availability of clean water sources used by residents to meet household needs and the efforts made by the community to overcome the lack of clean water in Ranggagata Village, Praya Barat Daya District, Central Lombok Regency. The research method uses qualitative research with data collection techniques in research using observation, interviews and documentation. Data analysis using an interactive model of analysis with reduction. The results of the study can be concluded that the availability of clean water in the village of Ranggagata has made every effort so that in 2020 it has been fulfilled and steps to overcome the shortage of clean water have received assistance from the village head and from the Regional Water Company.
\end{abstract}

\section{A. LATAR BELAKANG}

Air merupakan sumber daya alam yang sangat penting dan mutlak diperlukan oleh makhluk hidup, baik manusia, hewan, dan juga tumbuhan. Bagi manusia, air digunakan untuk aktivitas metabolisme pelarut mineral/kimia, pelapuk mineral, dan mengimbangi penguapan. Selain itu air juga digunakan untuk kebutuhan sehari hari seperti keperluan rumah tangga, keperluan industri, keperluan pertanian, keperluan pertambangan, dan sebagainya (Daud, 2003:11). Kebutuhan manusia terhadap air bersih, selalu mengalami peningkatan dari waktu ke waktu, bukan saja karena meningkatnya jumlah manusia melainkan juga karena meningkatnya intensitas dan ragam dari kebutuhan air tersebut (Daud, 2003:11).

Berdasarkan observasi awal di Desa Ranggagata Kecamatan Peraya Barat Daya Kabupaten Lombok Tengah " yang mana daerah ini mengalami masalah pada sumber air bersih, Desa Ranggagata yang melakukan berbagai cara dalam memenuhi kebutuhan air bersih, misalnya dengan mencari sumber air ke tempat lain, melakukan pengolahan lebih lanjut pada sumur gali, Dalam usahanya demi memenuhi kebutuhan air bersih tersebut, kemungkinan beberapa penduduk mencari air ke sumber lain, yang airnya tidak mengalami masalah seperti mereka, sebagian lagi memilih untuk melakukan pengolahan lebih lanjut pada sumur gali yang mereka miliki dengan cara menambahnkan alat yang dapat memperjernih air sumur mereka, Sisanya memenuhi kebutuhan air bersih dengan cara membeli air dalam bentuk galon atau jerigen yang dijual pada toko-tokoh tertentu.

\section{B. METODE PENELITIAN \\ 1. Rancangan Penelitian}

Metode penelitian yang digunakan dalam penelitian ini adalah metode penelitian kualitatif, dengan teknik pengumpulan data menggunakan observasi, wawancara, dan dokumentasi. Untuk menganalisis data penliti menggunakan model interaktif analisis dengan reduksi yaitu merangkum/meringkasdata. 


\section{Lokasi Penelitian}

Penelitian ini dilakukan Di Desa Ranggagata Kec. Praya Barat Daya Kabupaten Lombok Tengah

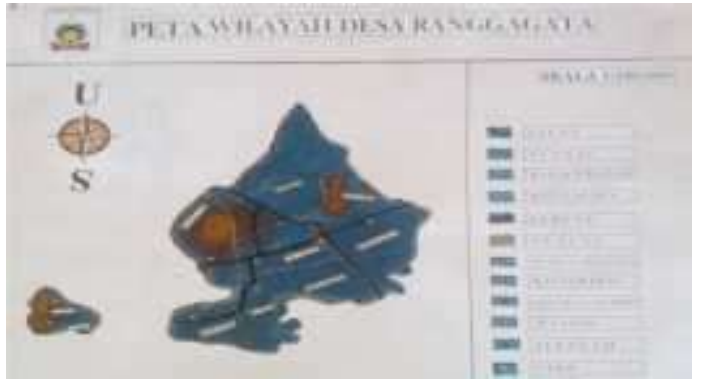

Gambar 1. Lokasi Penelitian

Sumber : Profil Desa Ranggagata (2018)

\section{Metode Penentuan Informan}

Dalam penelitian ini, peneliti mengunakan informan sebagai subjek penelitian. Informan ada dua yaitu informan kunci dan informan biasa:

a. Informan kunci adalah infomasi yang memiliki peranan penting dalam pengumpulan data berupa kata_kata yang menjadi informan kuncidalam penelitian ini ialah Kepala Desa, Sekertaris Desa,Perangakat Desa dan PDAM.

b. Informan biasa adalah orang yang bersedia memberikan informasi yang didapatkan pada informan kunci. Yang bias menjadi infoman biasa adalah Masyarakat Desa Yang jumlahnya 10 orang terdiri dari (2 Kepala Dusun dan 8 Masyarakat Desa ).

\section{Jenis dan Sumber Data}

\section{a. Jenis Data}

Jenis data di bagi menjadi dua yaitu :

1) Data kualitatif merupakan jenis data yang berhubungan dengan kategorisasi, karakteristik berjudul pertanyaan berupa kata-kata.

2) Data kuantitatif merupakan data yang berwujud angka-angka, maka dalam penelitian ini adalah kuantitatif( sugyono, 2013).

Dalam penelitian ini peneliti mengunakan penelitian kualitatif karena data yang di sajikan berupa kata-kata dan kalimat.

\section{b. Sumber Data}

Sumber data dapat di bagi menjadi dua yaitu :

1. Data primer merupakan sumber data yang langsung di berikan data kepada pengumpulan data.

2. Data sekunder merupakan sumber data yang tidak langsung diberikan kepada pengumpulan data

Sumber data yang digunakan dalam penelitian ini yaitu sumber data primer dan data Sekunder. Instrumen Penelitian

\section{Metode Pengumpulan Data}

Adapun teknik pengumpulan data yang akan digunakan dalam penelitian ini adalah sebagai berikut:

\section{a. Metode Observasi}

Dalam penelitian ini peneliti mengunakan
Observasi Terus Terang atau Tersamar. Peneliti dalam melakukan pengumpulan data menyatakan terus terang kepada sumber data, bahwa ia sedang melakukan penelitian. Jadi mereka yang diteliti mengetahui sejak awal sampai akhir tentang aktivitas peneliti.

\section{b. Metode Dokumentasi}

Dokumentasi merupakan data sekunder yang dipandang perlu dalam penelitian ini, dalam upaya mendukung dan melengkapi data wawancara dan observasi, sehingga data ini menjadi lengkap.Dalam hal ini, data dari monografi desa, catatan, buku, foto, kebijakan, peraturan, dan Biro Pusat Statistik dan arsip lokasi yang bersangkutan. Dalam penelitian ini peneliti akan melakukan dokumentasi, di Desa Ranggagata Kecamatan Praya Barat Daya Kabupaten Lombok Tengah.

\section{c. Metode Wawancara}

Dalam wawancara yang di lakukan bentuk pertanyaan yang di buat harus dengan $5 \mathrm{~W}-1 \mathrm{H}$. Diantaranyamenanyakan tentang kendala yang di hadapi dalamketersediaan air bersih untuk Rumah tangga di Desa Ranggagata Kecamatan Praya Barat Daya Kabupaten Lombok Tengah.

\section{Teknik Analisis Data}

Analisis data merupakan proses mencari dan menyusun secara sistematis data yang diperoleh dari hasil wawancara, catatan lapangan, dan dokumentasi (Sugiyono, 2016).

\section{a. Reduksi Data}

Mereduksi data berarti merangkum, memilih hal-hal yang pokok, memfokuskan pada hal-hal yang penting, dicari tema dan polanya dan membuang yang tidak perlu.

b. Penyajian Data

Penyajian data merupakan sekumpulan informasi tersusun yang memberi kemungkinan adanya penarikan kesimpulan. Hal ini dilakukan dengan alasan data-data yang diperoleh selama proses penelitian kualitatif biasanya berbentuk naratif, sehingga memerlukan penyederhanaan tanpa menguraiisinya.

\section{c. Kesimpulan atauVerifikasi}

Kesimpulan atau verifikasi merupakan tahap akhir dalam proses analisa data. Pada bagian ini peneliti mengutarakan kesimpulan dari data-datayang telah diperoleh.Kegiatan ini dimaksudkan untuk mencari makna data yang dikumpulkan dengan mencari hubungan, persamaan ,atau perbedaan. Penarikan kesimpulan bisa dilakukan dengan jalan membandingkan kesesuaian pernyataan dari subjek penelitian dengan makna yang terkandung dengan konsep-konsep dasar dalam penelitian tersebut.

\section{PEMBAHASAN}

1. Ketersediaan Sumber Air Bersih Di Desa Ranggagata Kecamatan Praya Barat Daya Kabupaten LombokTengah 
Melihat ketersediaan air bersih yang di butuhkan untuk berbagai kebutuhan sepanjang tahun maka perlu di ketahui kendala berdasarkan survei peneliti di antaranya adalah belum ada pendistribusian dari dinasPDAM.

a. Ketersediaan Jumlah Penduduk Yang Memanfaatkan Sumber Air Dari Sumur Gali

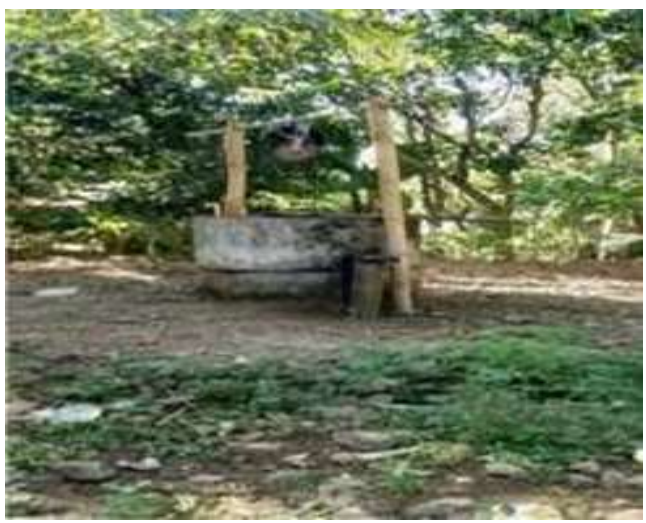

Gambar 1. Sumur gali penduduk

Sumber :Doc.profil Desa Ranggagata, 2018

Penduduk yang memanfaatkan sumur gali sebagai sarana sumber air bersih di Ranggata untuk kebutuhan hidup sehari-hari bisa dikatakan adalah sebagian besar penduduk yang memang berdekatan tempat tinggalnya dengan posisi atau letak dari sumur gali tersebut

Tabel 1.

Jumlah penduduk yang memanfaatkan air dari sumur gali

\begin{tabular}{cccc}
\hline No & DUSUN & PENDUDUK & $\begin{array}{c}\text { JUMLAH } \\
\text { SUMUR }\end{array}$ \\
\hline 1 & Berobot & 561 & 65 \\
2 & Aik ampat & 540 & 45 \\
3 & Dise & 1275 & 50 \\
4 & Aik gamang & 537 & 40 \\
5 & Kemek & 228 & 35 \\
6 & Gerunung & 240 & 48 \\
7 & Kumbak & 195 & 25 \\
8 & Batu bintang & 162 & 25 \\
9 & Montong & 231 & 45 \\
10 & Dasan Dao & 1.200 & 60 \\
\hline \multicolumn{4}{c}{ Sumber :Doc.profil Desa Ranggagata, 2018 }
\end{tabular}

Sumber :Doc.profil Desa Ranggagata, 2018

Berdasarkan tabel di atas dapat disimpulkan bahwa yang menggunakan sumur gali di desa Ranggagata kecamatan praya barat daya sangat sedikit oleh karena itu aparat desa ataupun dinas berusaha untuk membuatkan sumur gali di setiap dusun

b. Sarana dan prasarana yang di gunakan dalam memenuhi Ketersediaan Air bersih

Sarana dan prasarana air bersih selama ini oleh penduduk tiap dusun di ambil dari sumur-sumur galian menual yang pada persentase jumlah sumur sumur dengan penduduk dusun sangat tidak seimbang, hal ini bisa kita liat di dusun dasan dao yang sumur galian manual sekitar 15 sumur berbanding dengan sekitar $300 \mathrm{KK}$.

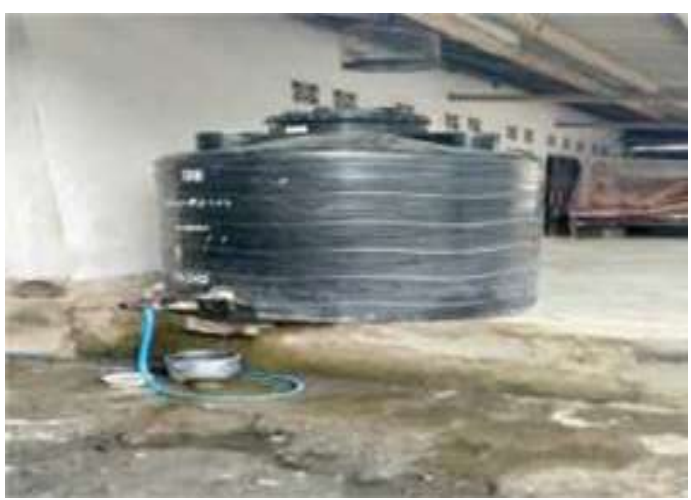

Gambar 2. Sarana dan Prasarana Air Bersih Sumber :Doc.profil Desa Ranggagata, 2018

\section{c. Tindakan Dari Pemerintah Desa Tentang}

Ketersediaan Air bersih

Salah satu tindakan yang dilakukan oleh pemerintah desa jika terjadi kelangkaan air bersih adalah dengan cara meminta bantuan Pemda atau Pemerintah daerah untuk menyalurkan tangkitangki air bersih

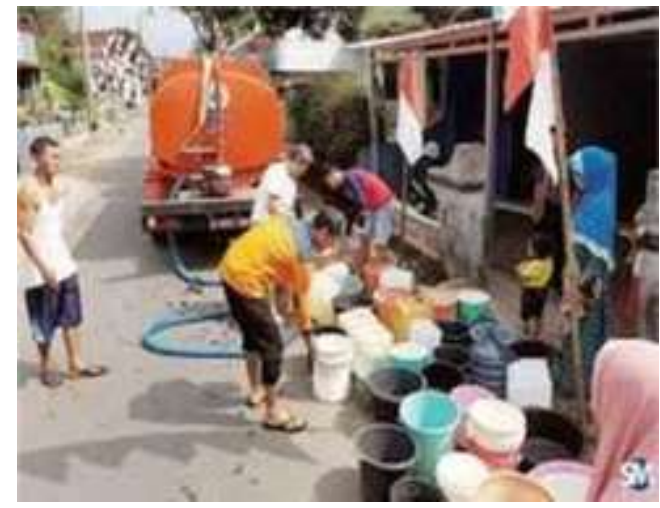

Gambar 3. Tindakan dari pemerintah Sumber : Doc.profil Desa Ranggagata, 2018

2. Upaya Dalam Menanggulangi Kekurangan Air Bersih Di Desa Ranggagata Kecamatan Praya Barat Daya Kabupaten Lombok Tengah.

Permasalahan krisis air bersih di kecamatan praya barat daya tidak hanya terjadi pada desa Ranggagagta saja tapi di desa yang lain juga sering mengalami kelangkaan air bersih, yang menjadi pertanyaan besar adalah mengapa di saat ini di lombok tengah banyak terjadi krisis air bersih terutama di Desa Ranggagata Kecamatan Praya Barat Daya Kabupaten LombokTengah

a. Upaya Dalam Menanggulangi Kekurangan Air Bersih Desa Ranggagata

Salah satu upaya yang akan dilakukan bahkan sedang dilakukan oleh Pemerintah Desa adalah mengupayakan semaksimal mungkin untuk membangun salah satu fasilitas sumur dengan melakukan pengeboran air tanah tangki-tangki air yang dilakukan ke seluruh dusun yang ada dengan mengatur jadwal pendistribusian air secara marata. 


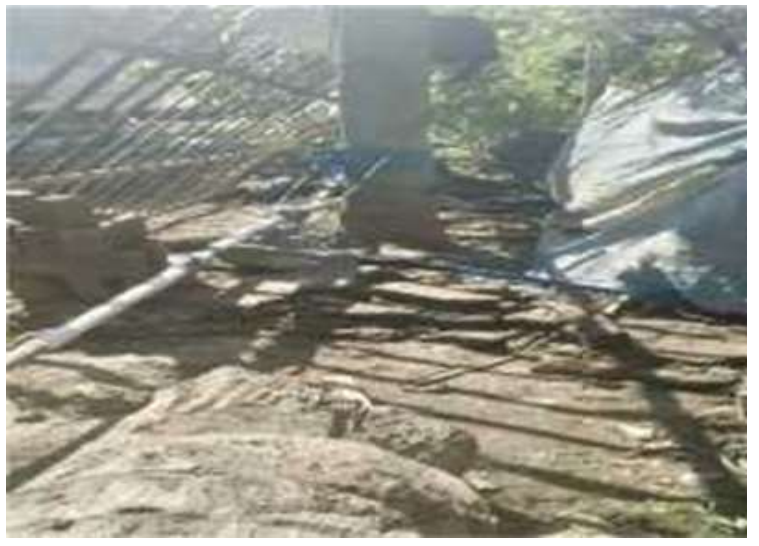

Gambar 4. Upaya Menanggulangi Kekurangan Air Sumber : Doc.profil Desa Ranggagata, 2018

b. Upaya Penyuluhan Dari Aparat Pemerintah Dalam Menanggulangi Kekurangan Air Bersih di Desa Ranggagata

Setelah terjadi beberapa kali pendistribusian air bersih yang tidak merata, pada akhirnya setelah adanya keluhan dari beberapa masyarakat atau warga maka pemerintah terkait khususnya Pemerintah Kabupaten Lombok Tengah turun langsung memberikan pengarahan kepada aparat desa

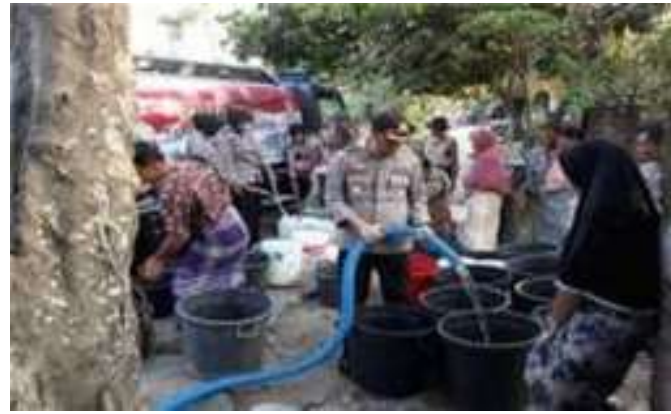

Gambar 5. Upaya penyulihan dari pemerintah Sumber : Doc.profil Desa Ranggagata, 2018

\section{SIMPULAN DAN SARAN}

\section{SIMPULAN}

Berdasarkan hasil analisis data dan pembahasan penelitian pada Bab sebelumnya,maka peneliti dapat menyimpulkan bahwa ketersediaan sumber air bersih untuk pemenuhan kebutuhan rumah tangga di Desa Ranggagata Kecamatan Praya Barat Daya Kabupaten Lombok Tengah Sebagai Berikut :

1. Dengan ketersediaan air bersih yang belum maksimal yang diakibatkan oleh curah hujan yang rendah dan ketersediaan tempat-tempat penampungan air yang kurang memadai mengakibatkan dampak yang sangat signifikan terhadap kesejahteraan masyarakat terutama akan ketersediaan air bersih untuk kebutuhan rumah tangga dan kebutuhan Air bersih di Desa Ranggagata disetiap dusun 256.815 (liter/ Hari ).

2. Salah satu upaya yang dilakukan oleh masyarakat adalah dengan melakukan pembuatan sumur gali disetiap dusun atau sumur yang dibuat oleh masyarakat dengan cara manual, hal ini dilakukan di berbagai lokasi dan hamper seluruh dusun yang ada di Desa Ranggagata, begitu juga dengan upaya yang dilakukan oleh pemerintah setempat yaitu dengan menyalurkan air bersih melalui tangki-tangki air yang dilakukan ke seluruh dusun yang ada dengan mengatur jadwal pendistribusian air secara marata

\section{SARAN}

Berdasarkan hasil analisis data dan pembahasan penelitian pada bab sebelumnya,maka peneliti dapat menyarankan bahwa Ketersediaan Sumber Air Bersih Untuk Pemenuhan Kebutuhan Rumah Tangga Di Desa Ranggagata Kecamatan Praya Barat Daya Kabupaten Lombok Tengah Sebagai Berikut :

1. Sarana untuk ketersediaan Air Bersihyaitu dengan melakukan penggalian sumur gali disetiap dusun baik yang dilakukan dengan manual maupun modern dengan memperhatikan tempat dan lokasi yang strategis sebagai upaya untuk pemerataan air untuk setiap dusun, dan masyarakat melakukan penghematan air di musim-musim tertentu terutama pada musim kemarau.

2. Salah satu upaya untuk mengatasi kelangkaan air bersih adalah dengan cara menghemat semaksimal mungkin penggunaan air dalam sekala besar, hal ini dapat dilakukan dengan adanya penyuluhan penggunaan air bersih oleh pemerintah setempat.

\section{DAFTAR RUJUKAN}

[1] Alihar, Fajri. (2019,feb.20 )Penduduk akses air bersih di kota semarang https :306-1006-2-pb (1) pdf [1]

[2] Handayani,Novi.(2010,Janu.3) Studi awal tentang penyediaan air bersih di desa karangduwer kecamatan kalikajar kabupaten wonosobo https:lib.unnes.ac.id/4168/1/8178.pdf [2]

[3] Kodoatie, Robert J, Suharyanto, Sangkawati Sri, Edhisono Sutarto", pengelolaan sumber daya Air Dalam otonomi Daerah : 2002 [3]

[4]K. Subagyono, H. Sosiawan. (2019,Janu 7 ) Strategi pembagian air secara peroporsional untuk keberlanjutan air,http//portal.garuda.com [4]

[5] Rizani DebyM.(2010Maret 2) Rendahnya tingkat pelayanan Air bersih bagi masyarakat ,https::/Tugas\%20Kuliah\%20Ansori/VI/ 221598-rendahnya-tingkat-pelayanan-air-bersihb.pdf [5]

[6] Sugyono,"Metode penelitian kuantitatif dan kualitatif :2013 [6]

[7] Sugyono,"Metode penelitian kuantitatif dan kualitatif :2018 [7] 